\title{
THE COURT EXPERT AS A MEANS OF EVIDENCE IN THE LITIGATION PROCEEDINGS
}

\author{
Vlatko Nacev', Vojo Belovski \\ ${ }^{1,2}$ Faculty of law - University "Goce Delcev" Stip, Macedonia \\ vlatkonacev@yahoo.com
}

Professional Paper doi:10.5937/jouproman6-18695

\begin{abstract}
The expertise as one of the legally defined means of evidence in litigation proceedings is an unavoidable procedural action without any litigation procedure can be successfully completed in the merits. The expertise is usually implemented in order to answer a specific factual subject important for making legal and precise decision about litigation proceedings. In the case of deciding about the implementation of legal form, the expertise is not applied and required.
\end{abstract}

There are a lot of opinions in the practice that the work of the expert witnesses is not at an appropriate and satisfied level related to the standards and criteria for an independent and efficient judiciary system. This is characterized especially in the countries where the justice system is unstable and completely not independent of the political and social influences, such as many other external and internal factors. In these countries, as the Republic of Macedonia, the expertise is also emphasized with subjective nature, where the findings and opinions are considered as insufficiently specialized and unprofessional.

However, there are exceptions to this rule. The court practice shows that there are court experts who perform their activities honestly, morally and professionally. Taking into consideration the great importance that court experts have with their findings and opinions in the litigation procedure, they have an influence on this complex process with their findings and opinions as legal evidence.

The court expertise, as means of proof in litigation, has a big importance. The judicial review as a means of proof in the litigation procedure is performed when in order to establish the facts or to clarify some of the particular circumstances a direct examination and observation by the court is required. That's why the court experts are distinguished as skillful persons who have professional knowledge, which is necessary for the court to verify the truth of certain assumptions and facts presented in front of the court form both sides.

Keywords: court expertise, a judicial system, findings, opinions, Republic of Macedonia

\section{INTRODUCTION}

The Law on Litigation Proceeding, as one of the preconditions for the functionality of the judiciary system, provides a direct action which is effective for all participants that have an impact on the outcome of the litigation procedure. This law regulates the rules of procedures for offering legal protection and according to this law the litigation cases for disputes arising from violation of the rights of the person and disputes from family, labour, social, property and other civil law relations are solved, except the disputes that need special legal frames another type of procedure is given.

In litigation procedure with the process of evidence, necessary facts for the adoption of court decision are determined. The evidence is pointed out through all the activities of the court and the parties that are undertaken in order for the court itself to determine the truth of one expressed assumption. For practical reasons, in order to avoid possible misconceptions, it should be always made difference between evidence and means of evidence. Evidence (Instrumentum) is a means by which the court receives knowledge of the truth about the fact that is important for passing a court decision. 
The evidence is a confirmation of the truth about the fact that is established through certain evidence. When it comes to the parties, they are obliged to present the facts and present the evidence on which their claim is based and their statement, or by which it disputes the allegations and evidence of the opposing party.

According to the Law, the evidence covers all the facts that are important for reaching the final decision. The court has the competence to decide which of the proposed evidence will take in consideration as decisive and important facts for the final decision.

The court experts are one of the means of evidence that the parties can use in the litigation procedure, while the court expertise is a function (action, activity, task, obligation, duty, work) of the court expert.

The law emphasizes that the court will determine the evidence obtained through a court expertise report if it comes to determining or clarifying some facts requiring specialized knowledge that the court does not itself have.

The court expert is independent in the performance of the expertise within the framework of the legal authorization determined by law and the court expert is obligated to perform the court expertise professionally and conscientiously in accordance with the rules of science and profession, ethical norms and professional standards.

The complexity of the litigation process itself and the increasing complexity of legal relations actually increase the number of situations in which the judge does not have the necessary knowledge for certain expert issues of immediate importance for the proper and legal settlement of the dispute.
The essence of the court expertise is in giving findings and opinions. The finding is a description of the subject matter of the expertise, while the opinion is a professional analysis or a professional conclusion which the court expert presents his expert knowledge for the subject matter of the expertise. According to the Law on Litigation Procedure, the deadline for submitting the expert finding and the opinion is determined by the court, which cannot be longer than 45 days, and in the complex cases, it cannot be longer than 60 days. The court shall deliver the expert finding and the opinion to the court participants no later than eight days before the hearing on which they will be discussed.

\section{THE CONCEPT AND DEFINITION OF COURT EXPERT}

Before undoubtedly pointing out the great importance of the expert witness as evidence in the litigation procedure, it is necessary to become familiar with the concept and definition of the court expert, the legal determination and the conditions for performing the expertise in the civil procedure.

Court proceedings in which the court experts do not appear as evidence or as specific supporters of the court are very rare. In English, these court experts are also known as Surveyors, in Italian Periti, and in German Gutachters.

In the Republic of Macedonia, the concept of a court expert is defined by the Law on Expertise: "The court expert" is a person who has a license for expertise in the respective field and is registered in the Register of Experts ${ }^{1}$.

\footnotetext{
${ }^{1}$ Law on court expertise (2010) - Official Gazette of Republic of Macedonia No. 115 date 31.08.2010
} 
In practice there are often numerous questions about the role and the importance that court experts have in court proceedings. The court experts are because in all of the explanations of the court proceedings there are allegations where the court fully accepts the opinion of the court experts as an opinion that is professional, complete and objective.

The legal theory defines the concept of expertise as an activity that brings more weight and complexity through the importance it has for the given court proceedings. From here, there are four different perceptions regarding the legal specificity of the expert witness's statement ${ }^{2}$ :

I. Court experts are scientific judges, referring to the expertise as a scientific judgment - the Court is free only in terms of determining the expertise but is not capable of assessing the results of the expert's activity.

II. The court expert is equated with the witness - it is more characteristic of the Anglo-Saxon legal system. Experts are scientific witnesses, while expertise is a scientific testimony.

III. The testimony of a court expert equates to judicial review - the court directly observes those facts for which there is no need for professional knowledge, while the expert points out and notes those facts and phenomena that require specific, complex and expert knowledge or knowledge.

IV. The testimony of the court experts is a self-evident means of specificity and certain similarities with the other evidence - this are one of the most modern legal theories for defining and explaining the notion of expert and expert.

\footnotetext{
${ }^{2}$ Arsen Janevski, Tatjana Zaroska Kamilovska (2001) - Civil proceeding law - administrative law, Faculty of Law "Justinijan Prvi" - Skopje, page $39-55$

The modern legal theory takes two main opposite views that refer to the fact that, on the one hand, the court experts are a proof means, while on the other hand, the experts are only the help and support of the factfinding.

If the court experts in their activity inform the court of their finding and opinion, their statement is classical evidence. However, if the court experts with their expertise help to form the necessary conclusions, in order to the court to form a certain opinion on the facts, then they perform the function of a specific facilitator in performing a proper and fair trial in determining legally relevant factual situations.

The most acceptable is the understanding that the court experts are persons whose statement serves as evidence, that is, expertise is a kind of evidence tool. The most complete definition of the legal institute of expertise is that, as a determinant of the expertise, it primarily emphasizes the application of special and specific knowledge, whose opinion is based on that knowledge, that is, the fact that the expertise creates new evidence. In fact, this definition significantly enters the content of the expertise as a source of awareness of facts based on professional knowledge, determining the essence of the expertise in relation to similar institutes and types of evidence.

The Law on Expertise directly stipulates the entities that can perform the expertise and the conditions that they need to fulfil for the performance of the function of the expert witness. The law on expertise specifies the entities that can perform the expertise:

1. Higher education institution, scientific institution and professional institution on the basis of authorizations determined by law if they have employed at least two persons with a license for expertise, 
2. An individual solicitor - an expert established in accordance with the Law on Trade Companies that fulfils the requirements of this Law and has employed at least one person with a license for expertise, and

3. A commercial company that is registered in accordance with the Law on Trade Companies and performs expertise in accordance with this Law and employs at least two persons with an expertise license.

Institutions and the company that meet the requirements for expertise in accordance with the Law on Expertise may also perform a super-expertise if they have employed at least three persons with an expertise license.

For certain matters, determined by law, an expertise can be performed by a state administrative body that employs at least two persons with an expertise license, and a super-expertise can be performed if there are at least three persons employed with an expertise license.

If there is no expert or institution in the Republic of Macedonia in a certain area and in other cases determined by law, an expertise can be performed by a foreign court expert or a foreign professional institution, according to the laws of the state in which they are registered and meet the conditions for performing an expert report.

\section{FUNCTION AND CONTENT OF COURT EXPERTISE}

There are several types of litigation in different areas, as well as varying degrees of complexity and scope; the expertise can also be ranked by category ${ }^{3}$ :

\section{$>$ Situational expertise - performed immediately after the}

\footnotetext{
${ }^{3}$ Janevski, A. I Kamilovska, Zoroska T. (2011) Civil proceeding law - administrative law, Faculty of Law “ Justinijan Prvi” - Skopje, page 22-32
}

completion of the inspection or during the inspection

Cabinet expertise - all material traces and evidence are processed - the documentation is relevant by the court expert, taking into account his specialization and knowledge in the field

\section{Complex expertise performed in cases where all partial expertise is collected which differ from one another and when there is a need to be checked and aligned in a single and complete} report.

The function of the expertise in the presentation of evidence in court consists of formulating and presenting findings and opinions of court experts. The findings of the court experts are the current expert analysis of the court expert, especially aimed at determining the content and specificity of certain relevant facts. The opinion of the court expert is a personal opinion of the court experts on the importance, the belief, the conditions, and the consequences of certain factors that could be of great importance for determining the truth in the process of proof.

The expert shall inform the applicants, i.e. the party in the litigation procedure, the court or another competent body that manages the procedure for the findings and opinion. Specifically, the court expert through his analyzes and knowledge, with his expert knowledge, helps to draw a conclusion on the observed matter, which means that when giving the opinion, the court experts actually work what should be done by the bodies that conduct the procedure, if they have the necessary expert knowledge regarding the facts and the actual facts that are the main subject of the expertise. 
The court is free in deciding whether it will determine the proof of expertise, where the exception is the rule on the duty of the court to determine another entity that will assist in the evidence procedure. The court should decide in fact about which professions or specialization should be the court expert for the specific subject of the expertise and the court procedure to which it refers. The suggestion may be submitted to the lawsuit for the submission of evidence with an expert report, a response to a lawsuit, submissions or at the latest at the first hearing at the main hearing ${ }^{4}$.

The court or other competent bodies that conduct the procedure are connected neither with the finding, nor with the opinion of the expert, but for the court expertise as a proof of their judgment and their conclusion after a careful assessment. This careful approach to analysis and evaluation is not directed only to the given evidence but is also implemented on the basis of the assessments of all other evidence individually and in their interaction. Accordingly, the court is not obliged to accept the finding and the opinion of the experts that the plaintiff filed with the lawsuit or defendant in response to a lawsuit, only because they are provided by persons who are permanent court experts. The finding and the opinion which one of the parties submits with the complaint or in response to the complaint is only an ancillary basis in the litigation procedure.

However, the role of the court expert in the significant co-operative procedures is reflected in the expert assistance of the body that administers the procedure in determining the fact, clarifying certain factual issues, and not for legal issues. This means that the court expert is neither called nor authorized by the authority conducting the procedure in any way to help resolve

\footnotetext{
${ }^{4}$ Law on Litigation - Consolidated text (2011) Official Gazette of Republic of Macedonia No.7 date 20.01.2011

legal issues and to apply certain legal norms.

\section{THEORY OF LEGAL PROCEEDINGS AND LITIGATION SUBJECTS}

Civil litigation is a general and basic method of settlement and decision making within civil law disputes. According to the Law on Litigation ${ }^{5}$, the rules of this procedure are applied by the competent courts in settlement and deciding on disputes arising from personal and family relations, labour relations, property and other civil legal relations, unless some of these disputes with specific legislative norms are placed under the jurisdiction of the other courts.

Considering the different civil legal relations, the civil procedure is divided into general and special procedures ${ }^{6}$. The rules of the general procedure are applied in situations when there is no regulation of any of the special procedures. According to the former individual understandings, the ultimate and basic purpose of the litigation procedure is the protection of subjective civil rights. It is undoubted that in the civil procedure a legally protection function is realized as a significant social activity, but in the procedure at the same time is offered protection of the subjective rights of the citizens and other legal entities. With the protection of subjective rights simultaneously the existing normative rules are realized in social relations.

Ius dicere - judicial practice significantly contributes to the development of the legal order. Any judicial verdict except an act of application of the law is real act of concretizing the general legal norms of the individual social situation.

\footnotetext{
${ }^{5}$ Law on Litigation (2005) - Official Gazette of Republic of Macedonia No.79 date 21.09.2005

${ }^{6}$ Chavdar, K. (2009) - Authorized lectures of Civil and Common Law , Skopje, University American College, page 50-62
} 
Despite the protective role, the procedure also implements a significant educational role. In fact, the court determines the reasons for the legal violations and pronounces a sanction for their removal in the litigation procedure. With this activity, the court has a profound impact on the citizens to behave in a spirit of respecting the law and morale in the country by encouraging the parties to resolve peacefully any given and specific dispute.

The concept of civil procedure is actually the procedure as a legal institution and is a complete method for the realization of judicial functions in civil-law disputes. The notion of a lawsuit is referred to a specific procedure conducted between the litigants, on the basis of the specific claim by the plaintiff and requires protection by the court. By mediation of the litigation, litigation procedures are adapted to the needs of each individual case in the exercise of the judicial function.

According to the basic concepts and aspects, the dispute is any situation that arises in the legal relations when the request arises in a conflict with a certain resistance or opposition to it. It is always a certain degree of disagreement between the two entities in the legal relationship. It usually precedes the litigation, but it does not necessarily lead to it. The subjects of the dispute have their own dispute which should be resolved by agreement or through arbitration. If one of the subjects requests court protection, then the litigation is processed as a procedural and legal relation. Although litigation is raised through the dispute, it is independent of its existence. The civil-legal relationship on the occasion of which the litigation arises can be prevented, but it will have no effect on the existence of the litigation as a procedural and legal relation.
The litigation subjects are primarily the legal parties and the court. In addition, legal attorney, authorized person, court experts, witnesses, interfering persons are also subjects in the litigation dispute. The subjects in the litigation procedure are in a certain relationship that is defined by procedural rules. The entities whose activities influence the beginning, process and finalization of the procedure are the parties and the court. The subjects, whose activities are not undertaken for themselves, but for the primary subjects are the advocates and the interfering persons. The subjects that do not take legal action are the court experts and witnesses.

\section{RESULTS FROM PERFORMING OF EVIDENCE OF COURT EXPERTS - FINDINGS AND OPINIONS}

After the court expertise, the court expert reports a summary to the court for the findings and gives an opinion. The facts that the court expert realizes or observes through the research within the rules of science and his profession knowledge are concrete findings. The court expert must describe the subject matter of the expertise and according to the condition of the case at the moment when the expertise is conducted. On the basis of the established facts presented in the finding, the court expert is obliged to express his opinion on the subject of the expert report. This opinion must be clear, documented and logically exposed. The duty of the expert is to complete and precisely explain his opinion, to state the way in which his assessments have been reached, i.e. conclusions regarding the examined and established facts.

The court submits to the parties a written finding and opinion prepared by the court expert before the hearing on which ones will be discussed. 
At this point, it can be concluded the fact that the court expert must always present his findings and explain his opinion, but if the parties in court procedure are not agreed the findings and opinions to be explained personally by court expert, then the finding and opinion must be read at the hearing in the absence of the expert (principle of the directness of performing the evidence).

The parties in the litigation procedure have the right to attend the expertise, ask the court expert to ask questions related to the subject matter of the expertise, and submit documents. These procedural actions are performed by the parties through the court. However, the failure of the court to ask the court expert to declare a certain decisive circumstance in relation to the finding, above the application of the parties, with this failure the court prevent the hearing and thereby violates the procedure. There is a violation of the procedure even if during the litigation procedure the court does not provide the parties with the written evidence and an opinion by the court experts at all or does not properly call the parties and fails to submit a written report and opinion to the court experts, or they do not properly invites the parties to a hearing in which the court expert orally presents his findings and opinion on any controversial fact that goes to the evidence substrate.

The finding, i.e. the description of the subject matter of the expertise is based on the opinion, as an expert judgement and analysis of the experts. If the court is not satisfied with the expertise, identifying deficiencies or inconsistencies, it may order the performance of a re-expertise from the same court expert. The opposing party may also hire another expert, if the facts are not sufficiently discussed, and the court may also appoint a new expert report with another court expert. If more court experts have been appointed and they provide a common finding and opinion, then the strength of the expertise that the court experts have brought is already emphasized. If in the finding and opinion they do not agree, each court expert specifies his findings and opinion.

When the data of the court experts on their findings do not agree essentially, or if the finding of one or more court experts is unclear, incomplete or in contradiction with itself or with the circumstances examined, and those deficiencies cannot be removed by re-hearing of the court experts, the court can determine a super expertise that will be performed in a deadline not longer than 45 days, and in complex cases it cannot be longer than 60 days. The super-expertise is determined by the president of the council or the individual judge electronically by applying the rule of random choice from the register of court experts, in the presence of both parties, and their attorneys.

Super-expertise of a higher degree is expert-critical expertise in two contradictory expertise, which can be performed by a team composed of at least three court experts from the appropriate area of a state administration body, higher education institution, scientific institution or professional institution, while the manner in which performed super-expertise is regulated by the actual procedural law.

\section{CONCLUSION}

Summarizing the above-mentioned topic of research regarding the significance of the court expert as evidence in the litigation procedure, it is a fact that the role of the court expert as evidence in the litigation procedure is almost invaluable. The development of the scientific evidence of the experts is becoming increasingly important within the judicial system and its development in the Republic of Macedonia. 
The expertise, as a task and obligation of the court expert, should be an exact, empirical work, free from subjectivity and bias, but is it always happen, it can be seen from the practical implementation of this evidence in numerous litigation procedures.

The court expert as evidence in the litigation procedure, free from subjectivity and bias, has a huge influence through the crucial process actions, on the effectiveness of the litigation procedure through a final decision based on the independence, professionalism, and knowledge of the court expert. The court experts have a great responsibility in the court proceedings, where it is observed from the practice of the courts in the Republic of Macedonia. It is very rare in the court practise where the competent court goes against the findings and opinions of the court expert from whom the court seeks assistance in determining the individual facts in the litigation proceedings.

It can also be concluded that the independence of the court affects the expertise as an evidence in the litigation procedures through the effectiveness of the procedural actions, referring in particular to the final decision through the last decision, where the legal nature of the expertise determining its crucial role through independent action is much more than just a process of checking evidence in litigation

In this context, it can be noted that often the outcome of the applied lawsuit in civil proceedings where the expertise is proposed as means of evidence, to a greater extent depends on the court expert and less than the court itself.

However, as previously mentioned in practice today, there are opinions that the work of the court expert is identified weaknesses and inconsistencies with occurrences of subjectivity, incompetence, inefficiency, and inconsistency in performing the expertise. This kind of work directly reflects and influences the court or civil proceedings. These negative phenomena and inconsistencies in the execution of the expertise in litigation procedures require the need for legal changes in the current Law on Expertise and amendments to the normative regulation in the field of expertise.

Legislative changes and normative regulation in the field of expertise should be aimed at achieving a higher degree of professionalism, expertise, and specialty of court experts and eliminating the possibility of corruption, subjectivity, and bias in performing the expertise. Having in mind the crucial importance of the expert witnesses as evidence in the litigation procedure, it is also necessary to determine a higher level of responsibility of the court experts in the process of undertaking the procedural actions.

With the new legal provisions, it is necessary to provide more frequent and mandatory training, continuous professional upgrading and improvement, and in particular, additional specialization of the experts in appropriate areas. The proposed measures are aimed at guaranteeing the professionalism and expertise of the court expert, as the characteristics on which the fair outcome of the litigation procedure depends.

The new legal solutions in the field of expertise should be in the direction and function of the timely, efficient and expert performance of the expertise, by observing the principles established in the international acts that treat the independence of the judiciary.

By adopting new more efficient norms and legal solutions in the field of expertise, it will be contributed to the realization of the final goal of creating an independent and efficient judiciary system as a guarantor for legal protection and security of citizens and other subjects in the society. 
(JPMNT) Journal of Process Management - New Technologies, International Vol. 6, No 4, 2018.

\section{REFERENCES:}

- Arnaudovski, Lj. - Judicial Management (2013) Skopje,

-Janevski, A. and Kamilovska, Zoroska, T. (2012) Civil Proceeding Law - Book First, Law on Litigation, (2nd edited edition), Faculty of Law "Justinian Prvi" - Skopje

- Arsen Janevski, Tatjana Zoroska Kamilovska, (2011) - Civil Pproceeding Law - Administrative Law, Faculty of Law " Justinian Prvi " - Skopje

-Georgievski, S. (2000) - Civil Proceeding Law, Kultura - Skopje

-Chavdar, K. (2009) - Authorized lectures on Civil Law and Common Law, University American College, Skopje

-Stanković, G. and Račić, R. (2008) - Law on Litigation, Trebinje

-Opatic N. (2004) - Court Experts an Evidence in Civil Procedure, Zagreb

- Law on Expertise (2010) - Official Gazette of the Republic of Macedonia No.115 date 31.08.2010

- Law on Litigation - Consolidated text (2011) Official Gazette of the Republic of Macedonia no. 7 date 20.01.2011

- Civil Proceeding Law (2005) - Official Gazette of the Republic of Macedonia no. 79 date 21.09.2005 